\title{
1 Deep-sea benthic megafaunal habitat suitability modelling: A global- scale maximum entropy model for xenophyophores
}

4 Oliver S. Ashford*a, Andrew J. Davies ${ }^{b}$, Daniel O. B. J ones ${ }^{a}$

6 a. National Oceanography Centre, European Way, Southampton, SO14 3ZH, UK

7 b. School of Ocean Sciences, Bangor University, Menai Bridge, LL59 5AB, UK.

* Corresponding author:

Present address: Department of Zoology, University of Oxford, Tinbergen Building, South Parks Road, Oxford, OX1 3PS, UK.

Email: oliver.ashford@zoo.ox.ac.uk

Telephone: (+44) 7763018136

\section{Abstract}

The Xenophyophorea is a group of exclusively deep-sea agglutinating rhizarian protozoans, at least some of which are foraminifera. They are an important constituent of the deep-sea megafauna that are sometimes found in sufficient abundance to act as a significant source of habitat structure for meiofaunal and macrofaunal organisms. This study utilised maximum entropy modelling (Maxent) and a high-resolution environmental database to explore the environmental factors controlling the presence of Xenophyophorea and two frequently sampled xenophyophore species that are taxonomically stable: Syringammina fragilissima and Stannophyllum zonarium. These factors were 
also used to predict the global distribution of each taxon. Areas of high habitat suitability for xenophyophores were highlighted throughout the world's oceans, including in a large number of areas yet to be sampled, but the Northeast and Southeast Atlantic Ocean, Gulf of Mexico and Caribbean Sea, the Red Sea and deep-water regions of the Malay Archipelago represented particular hotspots. The two species investigated showed more specific habitat requirements when compared to the model encompassing all xenophyophore records, perhaps in part due to the smaller number and relatively more clustered nature of the presence records available for modelling at present. The environmental variables depth, oxygen parameters, nitrate concentration, carbon-chemistry parameters and temperature were of greatest importance in determining xenophyophore distributions, but, somewhat surprisingly, hydrodynamic parameters were consistently shown to have low importance, possibly due to the paucity of well-resolved global hydrodynamic datasets. The results of this study (and others of a similar type) have the potential to guide further sample collection, environmental policy, and spatial planning of marine protected areas and industrial activities that impact the seafloor, particularly those that overlap with these conspicuously large single-celled eukaryotes.

Keywords: Maxent; species distribution modelling; Xenophyophorea; Syringammina fragilissima; Stannophyllum zonarium.

\section{Introduction}

Xenophyophores (Schulze, 1904) represent some of the most remarkable megafauna in the deepsea. These giant rhizarian protozoans build agglutinated tests that, in some cases, reach diameters of over $20 \mathrm{~cm}$ (Tendal, 1972; Levin and Thomas, 1988; Gooday et al. 2011), and were first described in the late $19^{\text {th }}$ century. Initially they were interpreted as a type of primitive foraminifera (Brady, 1883) or alternatively as a group of horny sponges living in symbiosis with hydroids (Haeckel, 1889). It was not until the early $20^{\text {th }}$ century that xenophyophores were recognised and named as a well defined group at a high taxonomic level within rhizopod protozoans (Schulze, 1904, 1907; Tendal, 1972; Pawlowski et al. 2003). Even with this taxonomic recognition, xenophyophores remained in relative obscurity for much of the $20^{\text {th }}$ century, and only after the publication of a landmark monograph in 1972 (Tendal, 1972) did the group became widely known 
amongst marine biologists in general (Gooday et al. 1993; Riemann et al. 1993; Pawlowski et al. 2003; Hughes and Gooday, 2004; Gooday et al. 2011).

Xenophyophores are a large, conspicuous component of the benthic megafauna found in all major ocean basins (Tendal, 1972; Levin, 1991; Levin and Gooday, 1992; Tendal, 1996) and can be enumerated in deep-water photographs (Kamenskaya et al. 2013) due to their often visually distinctive agglutinated tests. These tests enclose a branching system of organic tubes containing the cell body (the granellare system) together with often voluminous masses and strings of waste material (stercomata) enclosed within an organic membrane (Tendal, 1972; Gooday et al. 2011). However, observations of living specimens are limited, and so many aspects of xenophyophore biology, reproduction and life cycle remains obscure (Pawlowski et al. 2003).

Two major xenophyophore lineages are recognised based on morphological criteria: the Psamminida (4 families, 14 genera and over 50 described species), most of which have rigid tests, and the Stannomida (1 family, 2 genera and $\sim 17$ described species), which have more flaccid tests, in general, ramified by proteinaceous fibres (linellae) (Tendal, 1972; Tendal, 1996; Gooday and Tendal, 2002; Bisby et al. 2010). Opinions about the phylogenetic position of xenophyophores have developed over time. Following initial attempts at classifying xenophyophores (Brady, 1883; Haeckel, 1889) (see above), Schultze (1907) concluded that they represent a distinct group of rhizopod protozoans, an opinion followed by many later workers (Tendal, 1972; Gooday and Tendal, 2002). Recently, however, phylogenetic analysis of small sub-unit ribosomal RNA sequences from Syringammina corbicula (Richardson, 2001) (Pawlowski et al. 2003), Aschemonella ramuliformis (Brady, 1884), Shinkaiya lindsayi (Lecroq et al. 2009) and Reticulammina cerebreformis (Gooday et al. 2011) support Brady's (1883) conclusions that xenophyophores are foraminiferans. However, no sequence data yet exists for stannomids, and so it remains to be proven that all xenophyophores are foraminiferans.

Confined to depths greater than about 500 meters, xenophyophores reach peak densities where particle flux to the seafloor is enhanced, such as beneath productive surface waters, in canyons, on areas of raised topography (seamounts or ridges, for instance), or on continental slopes (Tendal, 1972; Tendal and Gooday, 1981; Levin et al. 1986; Levin and Thomas, 1988; Levin, 1994; BuhlMortensen et al. 2010; Gooday et al. 2011). Xenophyophores may live infaunally in soft mud, but 
most are epifaunal and live on soft sediment or attached to hard substrates (e.g. Tendal and Gooday, 1981; Gooday et al. 2011; Kamenskaya et al. 2013). They are likely to feed on a diet comprised mainly of detrital particles that are obtained via suspension feeding, surface-deposit feeding or by being trapped within the complex morphology of the test (Tendal, 1972; Lemche et al. 1976; Levin and Thomas, 1988; Gooday et al. 1993). It has further been suggested that xenophyophores are able to prey on small metazoans (Levin and Gooday, 1992; Smith and Demopoulos, 2003), and may 'farm' microbes as secondary food sources (Tendal, 1979; Laureillard et al. 2004; Hori et al. 2013), although there is no direct evidence for either of these feeding modes (A. Gooday, personal communication).

Xenophyophores sometimes play a significant role in biological processes that occur at the sediment-water interface (Tendal, 1972; Levin and Thomas, 1988; Levin and Gooday, 1992) and large morphologically complex species of genera such as Reticulammina (Tendal, 1972) and Syringammina (Brady, 1883) can be considered as autogenic ecosystem engineers. For example, xenophyophore tests provide a focus for organic carbon deposition, serving as traps of organic-rich sedimenting particles and add physical heterogeneity to seafloor mineralisation processes (Levin and Thomas, 1988; Levin and Gooday, 1992). Xenophyophore tests represent important habitatforming structures on the seafloor, contributing significantly to deep-sea biological heterogeneity (Levin and Thomas, 1988; Levin, 1991; Levin and Gooday, 1992; Smith and Demopoulos, 2003; BuhlMortensen et al. 2010; Hori et al. 2013). As a result, large complex tests appear to constitute faunal hotspots in the deep sea (Levin, 1991; Levin, 1994; Hughes and Gooday, 2004), with enhanced faunal densities and species richness (particularly of crustaceans, molluscs, echinoderms, foraminifera and bacteria) in their close vicinity (Levin et al. 1986; Hori et al. 2013).

As such, some xenophyophore species may represent an effective umbrella taxon, and knowledge of their distributions has the potential to be used as a guide, in addition to further information on the distribution of vulnerable marine ecosystems, as to which regions could be designated as marine protected areas (MPAs). Certain areas with abundant xenophyophores may be important for deepsea biodiversity and so should be considered for protection from human practices that disturb the seafloor, like deep-sea trawling, oil and gas extraction and mining. 
The great utility of global habitat suitability modelling is in the determination of the potential distributions of taxa that cannot be easily mapped using traditional methods. This is commonly the case in deep-water marine environments, which are difficult to sample due to barriers of cost and isolation. Species distribution models are informative in the context of general scientific investigations (e.g. in targeting regions for further research), but additionally, in cases where the investigated group is of conservation concern (being vulnerable to anthropogenic disturbance and/ or important in the functioning of ecosystems) these models can be instructive in directing the designation of protected areas (Davies and Guinotte, 2011; Yesson et al. 2012). Maximum entropy modelling (Maxent) (Phillips et al. 2006) is a machine-learning habitat suitability modelling method that produces a niche model by minimising the relative entropy between two probability densities; one estimated from the input presence data and the other from the environmental parameters of the landscape in question (Tittensor et al. 2010; Elith et al. 2011). Maxent has been shown to be one of the highest performing (i.e. most accurate) habitat suitability modelling techniques available (Elith et al. 2006; Ortega-Huerta and Peterson, 2008; Wisz, et al. 2008). However, its accuracy can drop substantially if a suitable number and variety of presence records are not available to guide the model, and/ or if the environmental data available are not reliable or do not fully encompass the range of environmental factors experienced by the focus taxon. There are known issues associated with species distribution models based on small numbers of presence records (Feely and Silman, 2011), including over-prediction, resulting in false positives (Anderson and Gonzalez, 2011), and false negatives. In terms of environmental variables, obtaining a highresolution global dataset currently requires up-scaling from lower-resolution data, and this inevitably introduces some error, which grows as the difference between native and required resolution increases (Davies and Guinotte, 2011). On balance however, distribution modelling at a global scale remains an instructive and informative technique.

This manuscript uses predictive habitat modelling to assess the global probability of occurrence of xenophyophores as a whole taxon and to explore the potential global distribution of the two most commonly recorded xenophyophore species that are also considered taxonomically stable: Syringammina fragilissima (Brady, 1883) and Stannophyllum zonarium (Haeckel, 1889). Xenophyophore distributions are modelled using a 30 arc-second environmental database, which allows for global modelling at relatively fine spatial scales. 


\section{Methods}

\subsection{Xenophyophore presence data}

141 A total of 837 independent presence records representing 68 xenophyophore species were obtained from peer-reviewed journals, cruise reports, the Global Biodiversity Information Facility (GBIF) and Ocean Biogeographic Information System (OBIS) (Table 1; Supplementary Table 1). Prior to analysis, this dataset was revised so that only a single record was retained within each 30 -arc second cell since multiple presence localities within a single 30 -arc second cell can cause habitat suitability values to be weighted in favour of the environmental conditions that exist in that cell (Davies and Guinotte, 2011). As a result, 569 presence records were retained for the distribution modelling of Xenophyophorea, 40 for Syringammina fragilissima, and 31 for Stannophyllum zonarium (Table 1).

Producing a robust species-level distribution model requires a sufficient number of presence records to represent the full observed niche of the species in question as well as confidence in the taxonomic stability and consistency of identification of the chosen species (i.e. that all available records represent a single species, rather than a suite of morphologically similar species). Aschemonella ramuliformis, Aschemonella scabra (Brady, 1879) and Reticulammina Iabyrinthica (Tendal, 1972) fit this first requirement, with a large number of geo-referenced samples available relative to other xenophyophore species (Table 1). However, there is considerable doubt concerning the taxonomic status of these Aschemonella (Brady, 1879) species, and they are probably morphotypes that encompass several similar species rather than representing discrete and consistently identified species (A. Gooday, personal communication). This concern also extends to Reticulammina labyrinthica, since it is unlikely that this name has been applied consistently in the literature (A. Gooday, personal communication). As a result, only two species remained for which numerically sufficient taxonomically reliable geo-referenced records were available: Syringammina fragilissima and Stannophyllum zonarium. Hence, only these species were subjected to distribution modelling.

\subsection{Environmental data}


In total, 25 environmental layers were produced for use in the Maxent (maximum entropy; Phillips et al. 2006) models (Table 2, and see Figure S4 for a correlation matrix of these layers). These were chosen based both on their ecological relevance and their availability at a global scale, and can be split into six broad categories: bathymetric variables (layers derived from a bathymetric grid), carbonate chemistry variables (measures of calcite saturation state), chemical variables (general chemical parameters including salinity, alkalinity and dissolved inorganic carbon amongst others), hydrodynamic variables (current flow), oxygen variables (combination of variables relating to oxygen availability and utilisation), and temperature variables (after Yesson et al. 2012). Productivity variables were not available for use owing to a rapid decline in data quality at latitudes greater than $\sim 70^{\circ} \mathrm{N}$ and S. Since all environmental grids must be of the same latitudinal extent for use in Maxent, and about $22 \%$ of xenophyophore presence records were from over $70^{\circ} \mathrm{N}$, the decision was made to abandon the use of productivity variables in order to maximise the number of presence records used in the models. However, apparent oxygen utilisation (AOU - the difference in dissolved oxygen concentration of a body of water and its equilibrium oxygen saturation concentration under the same physical and chemical parameters - relating to the use of oxygen due to organismal respiration (Garcia et al. 2006a)) was available as a variable, and can be considered a proxy for respiration, which in turn correlates with rates of particulate organic carbon (POC) reaching the benthos (Pfannkuche, 1993).

Terrain attributes were extracted from bathymetric data (SRTM30 - a topographical layer produced from a combination of data from the U.S. 'Shuttle Radar Topography Mission' and the U.S. Geological Survey's 'Global 30 Arc-Second Elevation Data Set') following techniques and algorithms described in Wilson et al. (2007). Individual approaches are detailed in footnotes within Table 2; a brief description of each variable is given here. Topographic position index (TPI) is an approach to determine topographical features based on their relative position within a neighbourhood, and can be calculated over fine or broad scales to capture smaller or larger terrain features respectively. This calculation has been developed into a GDAL tool (Geospatial Data Abstraction Library) and the approach is described in Wilson et al. (2007). Slope was calculated using DEM Tools for ArcGIS developed by J enness (2012), in particular the 4-cell method of calculating slope, which is accepted as the most accurate approach (J ones, 1998). Here, slope is defined as the gradient in the direction of the maximum slope. Curvature attempts to describe general terrain features and may 
provide an indication of how water interacts with the terrain. Plan and tangential curvature describe how water converges or diverges as it flows over relief, whilst profile curvature describes how water accelerates or decelerates as it flows over relief (J enness, 2012). Aspect is defined as the direction of maximum slope and was converted to continuous radians following Wilson et al. (2007). Rugosity, terrain ruggedness index and roughness all describe the variability of the relief of the seafloor (Wilson et al. 2007). Rugosity is defined as the ratio of the surface area to the planar area across a neighbourhood of a central pixel (J enness, 2012) while terrain ruggedness index is defined as the mean difference between a central pixel and its surrounding cells and roughness as the largest inter-cell difference of a central pixel and its surrounding cell (Wilson et al. 2007). Roughness is calculated as the difference in value between the minimum and maximum bathymetry within a neighborhood (Wilson et al. 2007).

All other variables were created using the up-scaling approach presented within Davies and Guinotte (2011). All data were available in a gridded form partitioned into standardised depth bins ('z-layers') with a depth range of $\sim 0-5500 \mathrm{~m}$. These z-layers facilitated the determination of approximate benthic habitat conditions (of greatest interest owing to the benthic nature of xenophyophores) on a global scale. This was achieved by the projection of each z-layer to its corresponding area of seafloor using the up-scaling approach (Davies and Guinotte, 2011). This process involved three steps: 1) each z-layer was initially interpolated using inverse-distance weighting to a slightly higher spatial resolution (usually $0.1^{\circ}$ ) in order to minimise potential gaps that could appear between adjacent z-layers due to non-overlap following projection on to the bathymetric layer. 2) These layers were re-sampled to match SRTM30 (Becker et al. 2009) resolution (the highest resolution global bathymetric dataset available) and so preserve as high a spatial resolution as possible. 3) Each re-sampled z-layer was draped over the SRTM30 bathymetric layer to provide an indication of conditions near the seabed. Due to the limitations of the global datasets currently available, it had to be assumed that conditions below the deepest z-layer available were stable to the seabed. However, this approach has been demonstrated to work well over global and regional scales (Davies and Guinotte, 2011; Guinotte and Davies, 2012). of the model (Beaumont et al. 2005), a small subset of the available environmental layers were 
selected for use in the final analyses. Owing to the co-variant nature of many of the layers in each of the six variable categories (Figure S4), a single variable from each category was selected to represent the influence of that category (following the method of Yesson et al. 2012). Variable selection for each category was based on the predictive power of models based on single environmental layers. This was measured using the Test AUC statistic (area under the receiver operating characteristic - ROC - curve; Fielding and Bell, 1997). The AUC statistic can be defined as the probability that a presence site is ranked above a random background site. Values vary from 0 (model performance worse than random) to 0.5 (model performance indistinguishable from random) to 1 (model is maximally predictive) (Fielding and Bell, 1997). Test AUC is quoted since it is more reliable than training AUC scores (Warren and Seifert, 2011). Thus the single variable that produced the greatest test AUC value in isolation for each biological category was selected to represent that category in the final analyses, and hence the final analyses utilised six environmental layers (Table 3 and Table 4).

\subsection{Maximum entropy predictions}

Maxent (Phillips et al. 2006) version 3.3.3k was used to perform the global distribution prediction analyses. Default model parameters were used (convergence threshold of $10^{-5}$, regularisation parameter of 1 and a maximum iterations value of 500, with 10000 points randomly selected as background data to construct the model and each model run setting aside $30 \%$ of presence records for model evaluation) since these settings have been shown to produce reliable results (Phillips and Dudik, 2008; Davies and Guinotte, 2011; Yesson et al. 2012). Higher regularisation parameter values were trialled for the more taxonomically inclusive model of Xenophyophorea to produce smoother response curves (Figure 2). However, this resulted in the production of over-generalised models, lower test AUC, increased differences between training and test AUC, and a less discriminatory model output.

Model performance was evaluated by considering entropy, test AUC, test gain, and test omission scores (see Phillips et al. 2006). The importance of each environmental variable was assessed using a jack-knifing procedure (by comparing the gain achieved by variables in isolation - jack-knife of regularised training gain). Response curves were produced to visualise how xenophyophore habitat suitability varied with each environmental factor analysed. 


\section{Results}

\subsection{Sample locations}

256

Xenophyophore sampling to date is patchily distributed throughout the world's oceans (Figure 1). Areas where the highest numbers of xenophyophores have been collected include the North Atlantic (the Porcupine Abyssal Plain, Rockall Bank, Monaco Basin, Cape Verde Plateau and along the MidAtlantic Ridge), the Gulf of Mexico, the South Atlantic (especially around the Rio Grande Rise and Mid-Atlantic, Atlantic-Indian and Walvis Ridges) and Atlantic portion of the Southern Ocean, the Arctic Ocean (Baffin Basin, Barents Sea, Nansen Basin, Amundsen Basin and Makarov Basin in particular), patchily in the Indian Ocean (Somali Basin and off the coast of South Africa in particular) the South China Sea, the Northwest Pacific Basin, the Peru Basin, and around New Zealand. In contrast, xenophyophores have been only sparsely collected from the majority of the Indian and Southern Oceans, the western Arctic Ocean, and the South Pacific Ocean.

The global distribution of xenophyophore samples (Figure 1) cannot be directly interpreted in terms of overall sampling effort, but the patterns described above suggest that deep-water investigations are concentrated close to nations with more established sampling programmes, as well as hinting of potential bias against more remote locations (the Southern Ocean, for instance).

\subsection{Variable selection} Test AUC scores for the models based on a single variable varied greatly - from a minimum value of 0.393 (topographic position index, Syringammina fragilissima) to a maximum of 0.987 (depth, Syringammina fragilissima) (Table 3). Considering the six variable groupings (Table 2), depth performed best of all bathymetric variables across the taxa, whilst the curvature variables and topographic position index consistently produced some of the lowest AUC scores. Calcite saturation state returned high AUC scores for all taxa analysed, as did all chemical variables analysed (with nitrate, phosphate and silicate in particular performing consistently well), oxygen variables (with apparent oxygen utilisation, in particular, scoring highly) and temperature. AUC values for hydrodynamic variables were generally low, but regional flow rate consistently outperformed 
vertical flow rate (Table 3). The highest scoring variables in each variable group for each taxon were chosen for use in the multivariate Maxent models (see Table 3 and Table 4).

\subsection{Multivariate model evaluation}

Test AUC scores for the multivariate Maxent models were high (Table 4), ranging from 0.836 (Xenophyophorea) to 0.997 (Syringammina fragilissima). Test gain values ranged from 0.841 (Xenophyophorea) to 4.580 (Syringammina fragilissima), while entropy values ranged from 8.632 (Xenophyophorea) to 4.512 (Syringammina fragilissima). Test omission scores were low, ranging from 0.200 (Xenophyophorea) to 0.000 (Syringammina fragilissima and Stannophyllum zonarium) (based on the maximum sensitivity plus specificity of the test dataset). These low omission scores indicate that few known presences were wrongly classified as absences by the models, and that the predicted presences were significantly more probable than that of random background pixels (Table 4).

\subsection{Taxa niches}

Jack-knife assessment of model regularised training gain was used to determine which three variables were most important in the production of each of the multivariate Maxent models (Table 4). Combining this with information present in Figure 2, the main environmental conditions for peak habitat suitability (defined as a logistic habitat suitability of $\geq 0.5$ ) - i.e. the niche - for each taxon were estimated. For Syringammina fragilissima these were a depth of between $\sim 835$ and $1180 \mathrm{~m}$, a calcite saturation state of between $\sim 2.56$ and 3.36, and a temperature of between $\sim 5.3$ and $7.7^{\circ} \mathrm{C}$. For Stannophyllum zonarium, these were a nitrate concentration greater than $37.5 \mu \mathrm{mol} \mathrm{I}^{-1}$, apparent oxygen utilisation values of between 4.50 and $6.32 \mathrm{~mol} \mathrm{O}_{2} \mathrm{~m}^{-3}$, and temperatures of between 1.6 and $4.7^{\circ} \mathrm{C}$.

It is more complex to estimate conditions of peak habitat suitability for Xenophyophorea since the model encompasses the varied habitat requirements of multiple species (including those described above) and hence produced variable responses that had multiple peaks (Figure 2). Considering this, high habitat suitability for the taxon occurred at nitrate concentrations of $\sim 12.5$ to $29.2 \mu \mathrm{mol} \mathrm{I}^{-1}$ and above $38.0 \mu \mathrm{mol} \mathrm{I}^{-1}$, oxygen saturations of between 6.6 and $42.6 \%_{2}{ }^{5}$, between 69.2 and 74.3 

$8.7^{\circ} \mathrm{C}$.

For Xenophyophorea and Syringammina fragilissima, temperature was the variable that both reduced the training gain by the greatest amount when omitted from the multivariate Maxent model and produced the highest gain when used in isolation. Hence, this variable contained the most useful information that was not present in the other variables used to construct the models and the most useful information when used in isolation (Table 4). For Stannophyllum zonarium, apparent oxygen utilisation contained the most information that was not present in the other variables and the most useful information when used in isolation (Table 4).

At the other end of the spectrum, regional flow rate consistently contributed very little to the Maxent multivariate models, whilst depth and calcite saturation state contributed relatively little to the niche model of Stannophyllum zonarium (Table 4).

\subsection{Areas of maximal habitat suitability}

For Xenophyophorea (see Figure 3 and Figure S1), areas of peak habitat suitability were centred on a range of bathymetric features, including continental slopes, subduction trenches, semi-enclosed seas, ridges, seamounts and plateaus. In the Atlantic, xenophyophore habitat suitability was high along all continental slopes, around the Rio Grande Rise, along the Walvis, Reykjanes and MidAtlantic Ridges, in the Gulf of Guinea, on the Cape Verde Plateau and plain, in the Angola, Porcupine and Biscay abyssal plains, the most westerly extent of the Mediterranean Sea, around Rockall Bank and the Icelandic Plateau, along the Davies Strait and in Baffin Bay, around the Flemish Cap, in the Gulf of Mexico, and in deep water areas off Florida and in the Caribbean Sea. Habitat suitability was essentially zero on all continental shelves, in all but the very western extent of the Mediterranean and Sargasso seas, on the Sohm and Hatteras Plains, and in the, Sierra Leone, Guinea, Brazil, Argentine and Cape Verde Basins. hotspots were centred upon the continental slopes, Voring Plateau, Greenland Sea, Denmark Strait, Baffin Bay, and Lomonosov Ridge (Figure 3). 
The Southern and Indian oceans exhibited only isolated areas of high habitat suitability for xenophyophores, relative to the Atlantic Ocean. These included points along continental slopes (save for the Antarctic continental slope), the South Tasman Rise and the Exmouth Plateau, along Broken Ridge, scattered points along Ninetyeast Ridge, parts of the Agul has, Madagascar and Mozambique plateaus, regions of the Carlsberg ridge, along the Chagos-Laccadive ridge, the Mascarene Plateau, and regions of high suitability in the north of the Bay of Bengal, the Lakshadweep Sea, Gulf of Aden and deepest parts of the Red Sea. Further south, the South Sandwich Trench is also notable for relatively high habitat suitability (Figure 3).

The Malay Archipelago exhibited very high habitat suitability for xenophyophores in general. Particularly suitable areas included the Andaman Sea (particularly Dreadnought Bank) and the South China Sea, Sulu Sea, Celebes Sea and Banda Sea. In the southwest Pacific, the Bismarck Sea, Ontong J ava Rise and regions of the Coral Sea showed areas of relatively high habitat suitability. Regions of suitable habitat were also found around New Zealand - particularly on the Challenger Plateau and Chatham Rise, and along the Kermadec and Tonga trenches and associated ridges (Figure 3).

In the Pacific proper, high habitat suitability was generally centred along subduction trenches, continental slopes and numerous seamounts. For example, along the Mariana, Ryukyu, IzuOgasawara, J apan and Kuril-Kamchatka trenches and associated ridges to the west, the Mid-Pacific Mountains, Emperor Seamount chain, and around the Hawaiian ridge and Islands. High habitat suitability was also highlighted along the Cocos and Carnegie Ridges, along the length of the PeruChile Trench, in the deep water off the Californian coast, the northern-most extent of the Bering Sea, in the deeper regions of the Sea of Okhotsk and to the west of the Ryukyu Islands (Figure 3).

The model for Syringammina fragilissima produced the smallest area of suitable habitat of the taxa investigated (Table 4, Figure 4, Figure S2), being restricted to around Rockall Bank, the Hebrides Terrace and Anton Dohrn Seamounts, Rosemary Bank, along the Wyville Thomson Ridge, points on the continental slope along the west of the United Kingdom, the Iceland-Faeroe Rise, the continental slope around Iceland and the Reykjanes Ridge, along the Mid-Atlantic Ridge close to the Azores, around the northernmost extent of the Labrador Sea, north of the Bahamas, along the shallowest regions of the Madagascar Plateau, and points around New Zealand (particularly in areas 
363

364

365

366

367

368

369

370

371

372

373

374

375

376

377

378

379

380

381

382

383

384

385

386

387

388

389

390

of the Campbell Plateau). However, it must be stressed that, due to the limited number of presence records available for this species, and their relatively clustered nature (and so the requirement of extrapolation over relatively large areas in the model - such as over the South Atlantic, North and East Pacific, Arctic Ocean and Indian Ocean), the above does not represent a definitive map of distribution for the species. The addition of further presence records (particularly in regions yet to be sampled) may alter the area of apparent high habitat suitability for Syringammina fragilissima.

The model for Stannophyllum zonarium (Figure 5 and Figure S3) highlights a broader distribution than for Syringammina fragilissima, with areas of maximal habitat suitability centred on the Pacific Ocean rather than the Atlantic Ocean. Areas of high habitat suitability include much of the East and Northeast Pacific (Guatemala Basin and Albatross Plateau in particular), along the northern slope of the Aleutian Trench, around the Hawaiian Islands and Ridge, the Mid-Pacific Mountains, along Sculpin Ridge, in the Aleutian Basin (particularly the northernmost extent), along the Emperor Seamount Chain, on the Hess and Shatsky rises, in the Kuril Basin, along the Mariana, Ryukyu, IzuOgasawara, J apan and Kuril-Kamchatka trenches and associated ridges to the west, to the South of J apan, the Ontong J ava Rise, Caroline Seamounts, and isolated areas in the Coral Sea. In the Malay Archipelago, areas of high habitat suitability include deep areas of the Andaman, Sulu and South China seas, the Celebes Sea, the Makassar Strait and North Banda Basin, and areas of the Molucca and Flores Sea. In the Indian Ocean, the northernmost extent of the Bay of Bengal, regions of the Arabian Sea and Gulf of Aden, points along the Mascarene and Chagos-Laccadive plateaus and areas of continental slope along the northern shores of the ocean show high habitat suitability for this species (Figure 5). However, as for Syringammina fragilissima above, this distribution should not be interpreted as definitive due to the relatively small number of presence records available (and the requirement of extrapolation in the model such as over the Indian, Atlantic and polar oceans). The addition of further presence records may alter the area of apparent high habitat suitability for Stannophyllum zonarium.

\section{Discussion}

\subsection{Habitat predictions and applications}


This exploratory study enhances both our knowledge of xenophyophore distributions and illuminates the controlling physical factors of these distributions. It is generally accepted that xenophyophores reach highest densities in regions of high surface productivity (Tendal, 1972), and in areas where the flux of organic particles is enhanced by topography (Levin and Thomas, 1988; Levin, 1994; Gooday et al. 2011), including seamounts, mid-ocean ridges, canyons, subduction trenches, plateaus and continental slopes (Lemche et al. 1976; Tendal and Lewis, 1978; Levin and Thomas, 1988; Levin, 1994; Gooday et al. 2011). These topographic features are associated with localised currents (e.g. Roden, 1987), and thus it is hypothesised that organic particles are concentrated in their vicinity, increasing food availability for xenophyophores. As an alternative, Levin and Thomas (1988) suggest that the localised current regimes around these topographic features result in an increased flux and/ or deposition of xenophyophore propogules. Whilst productivity or localised current flow data were not available for use in this analysis (although apparent oxygen utilisation can be thought of as a proxy for productivity, and terrain variables can capture topographical driven flow information), predicted xenophyophore distributions (Figures 3, 4 and 5) were broadly concordant with the accepted views above. High habitat suitability scores were commonly obtained for mid-ocean ridges, continental slopes, plateaus, seamounts and the slopes of subduction trenches. This suggests that these topographic features may be associated with additional environmental characteristics positive to xenophyophore growth. Interestingly, in addition to the topographic features outlined above, this analysis suggests that deep semi-enclosed seas and bays may also be favourable to xenophyophore growth. For example, Baffin Bay, the Gulf of Mexico, the Caribbean Sea, the South China Sea, Andaman Sea, Sulu Sea, Celebes Sea and Banda Sea all exhibit

412 high habitat suitability (Figure 3), although the Mediterranean Sea is an exception to this.

413 Comparison of the global sampling distribution (Figure 1 ) and the habitat suitability map for xenophyophores (Figure 3) reveals that some xenophyophores have been sampled from areas with relatively low predicted habitat suitability. These include the Mediterranean Sea, the Southern Ocean and along the coast of Antarctica, around the southernmost extent of the Brazil Basin and northernmost extent of the Argentine Basin, to the southeast of Sri Lanka, to the north of Madagascar and parts of the Northwest Pacific and Arctic Ocean. Incorrect identification or spatial referencing errors may explain some of these records. Alternatively, the xenophyophore distribution model may not fully reflect the potential distribution of the group, or these samples 
may represent collection of xenophyophores in fringe habitats where they naturally occur at low densities.

When xenophyophore sampling locations (Figure 1) are compared with the Maxent habitat suitability maps (Figures 3, 4 and 5) it is demonstrated that a significant number of locations with high predicted xenophyophore habitat suitability are yet to be sampled. For Xenophyophorea, these include much of the western Arctic Ocean, the Icelandic Plateau and Reykjanes Ridge, most of Baffin Bay and the Labrador Sea, around the Flemish Cap, much of the Caribbean Sea, the Angola Basin, many locations along the continental slopes of the East and West Atlantic, most of the MidAtlantic Ridge, the Madagascar and Mascarene plateaus, the Gulf of Aden, the north of the Bay of Bengal and much of the Indian Ocean continental slopes of Australia, the Andaman Sea and seas around Sulawesi in the Malay Archipelago, around the Ryukyu Islands, the Ontong J ava Rise, the northernmost extent of the Bearing Sea, much of the Sea of Okhotsk, and numerous seamounts in the Pacific Ocean which are yet to be investigated. For Syringammina fragilissima, such areas are less numerous, but include the Reykjanes Ridge and the Mid-Atlantic Ridge around the Azores, the northernmost extent of the Labrador Sea, and potentially to the north of the Bahamas and on Walters Shoal of the Madagascar Plateau. For Stannophyllum zonarium, such areas are numerous and include much of the East and Northeast Pacific, along the Hawaiian and Boudeuse ridges, the deepest parts of the Bering Sea (particularly the northern slopes of the Aleutian Basin), along the Emperor Seamount Chain, along the major trenches of the West Pacific, on the Ontong J ava Rise, the Andaman, South China, Sulu, Celebes and Banda Seas, the north of the Bay of Bengal, and the Arabian Sea. These locations represent key targets for future sampling.

In regions where there is a perceived threat to benthic environments, the presence of a high density of large, morphologically complex xenophyophore species, in conjunction with other vulnerable marine ecosystems, could be considered as further motivation for the instalment of deep-water MPAs, since many xenophyophore species are important but fragile autogenic ecosystem engineers, playing a significant role in biological processes that occur at the sedimentwater interface (Tendal, 1972; Levin and Thomas, 1988; Levin, 1991; Levin and Gooday, 1992; Smith and Demopoulos, 2003; Hughes and Gooday, 2004; Hori et al. 2013). For instance, this analysis provides possible direction for the instalment of MPAs in areas of high predicted 
xenophyophore habitat suitability that are currently subjected to deep-sea bottom trawling. Such areas include a large number of seamounts, banks, ridges and plateaus across the world's oceans (Figure 3) (e.g. see Koslow et al. 2000 and Thrush and Dayton, 2002), and, indeed, some such areas have already been protected based on evidence of the presence of vulnerable marine ecosystems (including xenophyophore aggregations) (e.g. the Darwin Mounds off the NW coast of Scotland (De Santo and J ones, 2007)). This analysis also potentially provides spatial guidance for the protection of areas vulnerable to local negative ecosystem impacts associated with deep-sea oil and gas drilling, such as around the 'Atlantic Frontier' drilling sites near the Faroe Islands and sites in the Gulf of Mexico (Glover and Smith, 2003) (Figure 3). Similar knowledge and data could be applied to help propose MPAs in areas earmarked for deep-sea mining operations, such as areas of the Manus Basin off New Guinea and the Havre Trough off New Zealand (Glover and Smith, 2003), and the Clarion-Clipperton Fracture zone in the Eastern Pacific (where xenophyophores are known to reach quite high abundances) (Kamenskaya et al. 2013) (Figures 3 and 5). However it should be stressed that, although the resolution of this analysis is very high for its global scale, it is not adequate for probing the fine-scale distributions of xenophyophores within areas of high apparent habitat suitability, and as such, targeted surveys and distribution modelling of potential MPA locations at local or regional scales should be undertaken before designation to ensure they are based on the highest quality observational data available (Rengstorf et al. 2012; Ross and Howell, 2012; Guinotte and Davies, 2012; Rengstorf et al. 2013).

\subsection{Taxa niches}

Depth was one of the most important variables defining habitat suitability for the taxa analysed (Table 4). Moving from sea-level to greater depths, habitat suitability increased to values over 0.5 only in depths greater than about $500 \mathrm{~m}$ (Figure 2). This agrees well with the accepted observation that xenophyophores are found in water depths greater than $\sim 500 \mathrm{~m}$ (Tendal, 1972; Levin, 1994; Buhl-Mortensen et al. 2010). The importance of depth was not unexpected since multiple factors of biological importance also change with depth, including light intensity, pressure, temperature, productivity, salinity, calcium carbonate saturation states, and many more chemical variables. The trough in xenophyophore habitat suitability between about 4800 and $6350 \mathrm{~m}$ depth was unexpected, however (Figure 2). It is possible that this is caused by unfavourable environmental conditions for 
xenophyophores at these depths, such as nutrient-depletion. Alternatively this trough could reflect the lack of environmental data available at depths of $>5500 \mathrm{~m}$ from many global data products (i.e.

481 World Ocean Atlas). What is most likely, however, is that this habitat suitability trough represents an artefact of poor sampling effort at these depths.

Nitrate concentration was found to be an important environmental parameter for Xenophyophorea as a whole and for Stannophyllum zonarium. Peak xenophyophore habitat suitability was found to occur in waters with relatively high nitrate concentrations, and at particularly high nitrate concentrations for Stannophyllum zonarium in particular (maximal habitat suitability at concentrations greater than $37.5 \mu \mathrm{mol} \mathrm{I}^{-1}$ ) (Figure 2). This finding agrees well with the notion of xenophyophores being most common in relatively nutrient-enriched waters (Tendal, 1972; Levin and Thomas, 1988; Levin, 1994; Gooday et al. 2011).

The importance of calcite saturation state as a habitat characteristic relevant to xenophyophore distributions (Table 4) has, to the authors' knowledge, never been explicitly stated, although it has been observed that xenophyophores exhibit a 'preference' for sand-sized particles in test construction (Levin and Thomas, 1988; Levin, 1994), and that foraminiferal tests are a common sand-sized component in many xenophyophore tests (A. Gooday, personal communication). It seems that for multiple (but certainly not all) xenophyophore species, a calcite saturation state $>1$ is associated with test production from recycled calcareous foraminifera. This would appear to be the case for Syringammina fragilissima, for instance, with this commonly foraminiferal-tested (Tendal, 1972) species occurring well above the carbonate compensation depth and experiencing peak habitat suitability in waters with a calcite saturation state of between $\sim 2.56$ and 3.36 (Figure 2).

Oxygen variables were important in model construction for Xenophyophorea and for Stannophyllum zonarium in this study. Per cent oxygen saturation was an important variable for Xenophyophorea (Table 4), with the taxon exhibiting peaks of habitat suitability at a range of saturations - from 6.6 up to $89.7 \% \mathrm{O}_{2}^{\mathrm{S}}$ (Figure 2). Such a broad range of suitable oxygen saturations demonstrates a high level of variability in oxygen requirements and tolerance amongst species in this taxon, although most xenophyophores have been sampled from relatively well-oxygenated regions (A. Gooday, personal communication). Apparent oxygen utilisation was the most important variable in the construction of the Maxent model for Stannophyllum zonarium. Interestingly, this species reaches 
peak densities at apparent oxygen utilisation values of between 4.50 and $6.32 \mathrm{~mol} \mathrm{O}_{2} \mathrm{~m}^{-3}$ (Figure 2). Such high values link well with the high nitrate concentration preferences of Stannophyllum zonarium, suggesting that this species is often sampled from productive nutrient enriched regions with particularly high associated biological activity.

Temperature was of consistent importance to all taxa investigated, and was the single most important variable in the construction of the Maxent models of Xenophyophorea and Syringammina fragilissima (Table 4). The two species investigated in detail exhibited discrete temperature windows of peak habitat suitability (between $\sim 5.3$ and $7.7^{\circ} \mathrm{C}$ for Syringammina fragilissima, compared to between $\sim 1.6$ and $4.7^{\circ} \mathrm{C}$ for Stannophyllum zonarium) (Figure 2). The relationship between xenophyophore occurrence and temperature has not been discussed in detail, although there is some mention by Tendal (1972). Here Tendal argues that, as xenophyophores are to be considered members of a distinct cold-water fauna, it is to be expected that they are restricted in their upper vertical distributions by increasing temperature with decreasing depth, although he does not expand as to why this should be. More generally, such relationships are well documented for marine invertebrates (e.g. see Orton, 1920 and Barras et al. 2009), with temperature being an important factor controlling growth rate and various aspects of reproductive physiology, mediated by its influence on biochemical reactions (Brown et al. 2004).

Finally, it is interesting to note the low AUC values (Table 3) and low jack-knife training gains (Table 4) that were obtained for the hydrodynamic variables for all taxa investigated (regional flow for Syringammina fragilissima being a potential exception). This was surprising since the importance of water flow for xenophyophores as suspension feeders has been stressed by many authors (Tendal, 1972; Tendal and Lewis, 1978; Levin and Thomas, 1988; Levin, 1994). However, hydrodynamic variables also performed badly in a recent study of cold-water coral distributions (known suspension feeders) (Yesson et al. 2012) which used a similar environmental dataset. Thus this poor performance is likely to represent a scale issue - with these global scale layers not accurately portraying local scale variations in current velocity associated with small topographic features (Yesson et al. 2012). Higher resolution data is required to shed further light on the importance of current flow for the distribution of megafaunal suspension-feeders (Mohn et al. 2014). 
538 Model performance was good for all taxa, with high test AUC and gain scores, and low test omission values. Test AUC and gain values were higher for the species investigated compared to xenophyophores as a whole, and were higher for Syringammina fragilissima than for Stannophyllum zonarium. This was probably a result of the greater level of clustering of Syringammina fragilissima sample locations relative to Stannophyllum zonarium. The models for Syringammina fragilissima and Stannophyllum zonarium had a less variable dataset to fit than for Xenophyophorea, with smaller total variance in the environmental parameters at their sampling localities (smaller entropy values - see Table 4) as a result of the smaller number of presence records used in the models. Thus the Maxent model could be fitted more tightly around the presence data.

There are known issues associated with species distribution models produced using small numbers of presence records (Feely and Silman, 2011), these chiefly being over-prediction, resulting in false positives (Anderson and Gonzalez, 2011), and false negatives. The use of presence records that are distributed across a large longitudinal and latitudinal range (as for the model for Xenophyophorea) should lower the risk of over-prediction, and in general, the models appear to have performed well. However, there is some evidence of small areas of false positives. For example, in Figure 3 (Xenophyophorea), relatively shallow areas ( $<500 \mathrm{~m}$ depth) of the Norwegian trough are highlighted as potentially suitable habitat (0.4-0.6 logistic habitat suitability), while in Figure 5 (Stannophyllum zonarium), small areas of the Shelikof Strait are highlighted as suitable habitat (0.7-0.9 logistic habitat suitability) in water depths of around $200 \mathrm{~m}$. Considering our current knowledge of xenophyophore bathymetric distributions (see above and Figure 2), these predictions almost certainly represent false positives, although only ground-truthing can confirm this. False negatives are harder to pinpoint in the Maxent predictions, but almost certainly occur to some extent in the models for S. fragilissima and S. zonarium presented here (considering the level of extrapolation across ocean basins from a relatively small number of presence records). The addition of further presence records (particularly in regions yet to be sampled) will help to better define the distributions of these two species and highlight any false negatives present in the current models. only other Maxent model yet produced for a xenophyophore species (Ross and Howell, 2012) 
566

567

568

569

570

571

572

573

574

575

576

577

578

579

580

581

582

583

584

585

586

587

588

589

590

591

592

593

594

595

represents a further way in which model performance can be evaluated. In general, the two models show a high level of similarity. High habitat suitability $(>0.6)$ for Syringammina fragilissima in the NE Atlantic is demonstrated in both models along the continental slope off Ireland and the United Kingdom, around the Hebrides Terrace and Anton Dohrn seamounts, around Rosemary Bank, and along the slopes of Rockall and Hatton banks. There are some areas where the two models disagree, however. For instance, the model of Ross and Howell predicts higher S. fragilissima habitat suitability around the slopes of Edoras and Fangorn banks and along the slopes of the Porcupine Seabight and Goban Spur relative to the model presented in this paper. In addition, the model presented in this paper predicts larger areas of high habitat suitability, relative to Ross and Howell (2012), for S. fragilissima to the south of the Wyville-Thomson Ridge, between Bill Bailey's Bank and Rosemary Bank, and in the Hatton-Rockall Basin. The overall similarity of the two models, however, gives further confidence to their predictions, especially so considering that they are produced from different data sets - Ross and Howell choosing only to use topographic data.

Choice of modelling resolution is an important factor when producing predictive species distribution models (Guisan et al. 2007). While higher resolution outputs are preferable when we need to capture environmental variability at small spatial scales (like the rapid changes in temperature that occur with distance across the Faroe-Shetland Channel (Oey, 1997)) and for visualising predictions, they do carry certain associated error and limitations (Davies et al. 2008; Davies and Guinotte, 2011). Since, other than depth, global environmental layers are not available at 30 arc-second resolution, variables have to be up-scaled from their native resolution to that required ( 30 arcseconds in this analysis - see Methods). Up-scaling inevitably introduces some error, with this error growing as the difference between native and required resolution increases (Davies and Guinotte, 2011). Examples of the manifestation of this error include the generalisation and smoothing of variables and the failure to incorporate small scale variability in the up-scaled layers that is not present in the lower resolution source data (Davies and Guinotte, 2011; Rengstorf et al. 2012). Further, the majority of global layers currently available that can be up-scaled represent annual means of values (in order to ensure a high number of samples to maximise certainty in the variables (Davies and Guinotte, 2011)). As a result, these layers do not capture any component of annual variability, a particular drawback when modelling highly seasonal high latitude regions. However, comparison of up-scaled data with GLODAP (Global Ocean Data Analysis Project) test bottle water 
596

597

598

599

600

601

602

603

604

605

606

607

608

609

610

611

612

613

614

615

616

617

618

619

620

621

622

623

624

data by Davies and Guinotte (2011) found the two datasets to be highly correlated, and hence the authors concluded that any issues associated with the up-scaling method are outweighed by its benefits.

Whilst the dataset utilised in this study comprised a high number and diversity of variables, there were still variables which may have been informative but were not available for use. Chief amongst these were productivity variables, such as measures of particulate organic carbon reaching the seafloor, and surface water chlorophyll a concentrations. These variables were not available for use owing to a rapid decline in data quality at latitudes greater than $\sim 70^{\circ}$ (see section 2.2). Substratum type is a further variable that would have been interesting to incorporate into this analysis as there is evidence for sediment-type preference in xenophyophores (Levin and Thomas, 1988). Unfortunately, a global environmental layer containing details of sediment type is not yet available, but progress is being made towards this goal (e.g. Shumchenia and King, 2010). Furthermore, the hydrodynamic variables used in this study under-performed and were not of sufficient sensitivity to capture local scale variation in flow rates associated with isolated topographic features such as seamounts. Thus, considering the current uncertainty surrounding xenophyophore feeding methods, it would be particularly interesting to incorporate a high resolution local current flow into future analyses. Such a layer is currently unavailable at a global scale, although advances are being made at the regional scale (Mohn et al. 2014).

Potential evidence for xenophyophore sampling bias has been mentioned in section 3.1. Firm evidence of sampling bias would imply that the current distribution of presence localities used in this study is not adequate to represent all potential environments from which xenophyophores can be sampled. This would potentially lead to false negatives in the Maxent outputs. Whether this is the case will only become apparent following further sampling and analyses.

The most conclusive way to validate or refute the predictions of this analysis (Figures 3-5) would be to directly test them in the field via 'ground-truthing' (Guinotte and Davies, 2012). Do we find xenophyophores in areas of predicted high habitat suitability that have not yet been sampled, like the Andaman Sea, or do these predictions represent false positives? There are some issues with this method. Assuming that a cruise to undertake this task could be funded, it would be a huge undertaking to systematically search an entire 30 arc-second cell of high predicted habitat 
suitability using ROVs or camera equipment, and subsampling may miss specimens as xenophyophore distributions may be patchy within this cell. However, it should be noted that xenophyophores have been recorded at very high densities in areas of suitable habitat (Tendal and Gooday, 1981), increasing the likelihood of discovery.

Finally, although species distribution modelling has progressed rapidly in recent years in terms of resolution (compare the results of Davies et al. (2008) with those of Davies and Guinotte (2011) and Yesson et al. (2012)) and model performance criteria (e.g. Warren and Seifert, 2011), clearly the availability of additional relevant environmental variables with global coverage at high resolution, and a growing number of reliable presence localities will continue to lead to ever an increasing accuracy of models suitable for a number of research and industrial applications.

\subsection{Conclusive remarks}

This study represents the first of its kind for xenophyophores at a global scale and serves to improve knowledge of their distributions and further illuminate details of their ecology. Additionally, this analysis draws attention to the possible use of these fragile and remarkable deepsea megafaunal ecosystem engineers in enhancing MPA planning and designation. However, this work represents but a first step and aims to motivate continued research into these intriguing and important organisms; testing model predictions with further sampling, performing local-scale highresolution analyses and addressing some of the still unanswered questions concerning xenophyophore ecology and physiology.

\section{Acknowledgements}

The authors would like to thank Prof. Andrew Gooday for his insightful comments and suggestions which have much improved this manuscript, Dr. Ole Tendal for advice concerning the availability of records of xenophyophore sampling locations, especially for Stannophyllum zonarium, and three anonymous reviewers for their detailed comments. Dr. Daniel J ones was funded for this work by the 
651 UK National Environment Research Council as part of the Marine Environmental Mapping Programme 652 (MAREMAP).

\section{6. References}

654

655

656

657

658

659

660

661

662

663

664

665

666

667

668

669

670

671

672

673

674

675

676

Anderson, R.P., and Gonzalez, I. J r. 2011. Species-specific tuning increases robustness to sampling bias in models of species distributions: An implementation with Maxent. Ecological Modelling 222: 2796-2811.

Barras, C., Geslin, E., Duplessy, J-C., and J orissen, F.J . 2009. Reproduction and growth of the deep-sea benthic foraminifer Bulimina marginata under different laboratory conditions. J ournal of Foraminiferal Research 39: 155-165.

Beaumont, L.J., Hughes, L., and Poulsen, M. 2005. Predicting species distributions: use of climatic parameters in BIOCLIM and its impact on predictions of species' current and future distributions. Ecological Modelling 186: 251-270.

Becker, J J ., Sandwell, D.T., Smith, W.H.F., Braud, J ., Binder, B., Depner, J., Fabre, D., Factor, J., Ingalls, S., Kim, S-H., Ladner, R., Marks, K., Nelson, S., Pharaoh, A., Trimmer, R., Von Rosenberg, J., Wallace, G., and Weatherall, P. 2009. Global bathymetry and elevation data at 30 arc seconds resolution: SRTM30_PLUS. Marine Geodesy 32: 355-371.

Bisby, F.A., Roskov, Y.R., Orrell, T.M., Nicolson, D., Paglinawan, L.E., Bailly, N., Kirk, P.M., Bourgoin, T., and Baillargeon, G. (Eds.). 2010. Species 2000 \& ITIS Catalogue of Life: 2010 Annual Checklist Taxonomic Classification. DVD; Species 2000: Reading, UK.

Biodiversity occurrence data published by: PANGAEA - Publishing Network for Geoscientific and Environmental Data; Danish Biodiversity Information Facility; Museum of Comparative Zoology, Harvard University; Yale University Peabody Museum; (Accessed through GBIF Data Portal, data.gbif. org, 2013-01-11).

Boyer, T.P., Levitus, S., Garcia, H.E., Locamini, R.A., Stephens, C., and Antonov, J.I. 2005. Objective analyses of annual, seasonal, and monthly temperature and salinity for the World Ocean on a $0.25^{\circ}$ grid. International J ournal of Climatology 25:931-945. 
677 Brady, H.B. 1879. Notes on some of the Reticularian Rhizopoda of the "Challenger" Expedition. Part

678 1. On new or little known arenaceous types. Quarterly J ournal of Microscopical Science 19: 20-63.

679 Brady, H.B. 1883. Syringammina, a new type of arenaceous Rhizopoda. Proceedings of the Royal 680 Society $35:$ 55-161.

681 Brady, H.B. 1884. Report on the Foraminifera. Report on the scientific results of the voyage of $H$.

682 M. S. Challenger 9: 1-814.

683 Brown, J.H., Gillooly, J.F., Allen, A.P., Savage, V.M., and West, G. B. 2004. Toward a metabolic 684 theory of ecology. Ecology 85(7): 1771-1789.

685

Buhl-Mortensen, L., Vanreusel, A., Gooday, A.J., Levin, L.A., Priede, I.G., Buhl-Mortensen, P., 686 Gheerardyn, H., King, N.J ., and Raes, M. 2010. Biological structures as a source of habitat 687 heterogeneity and biodiversity on the deep ocean margins. Marine Ecology 31: 21-50.

688

Carton, J.A., Giese, B.S., and Grodsky, S.A. 2005. Sea level rise and the warming of the oceans in 689 the SODA ocean reanalysis. J ournal of Geophysical Research 110: C09006.

Davies, A.J ., and Guinotte, J.M. 2011. Global habitat suitability for framework-forming cold-water corals. PLOS ONE 6: e18483.

Davies, A.J ., Wisshak, M., Orr, J.C., and Roberts, J.M. 2008. Predicting suitable habitat for the cold-water reef framework-forming coral Lophelia pertusa (Scleractinia). Deep Sea Research Part I: Oceanographic Research Papers 55: 1048-1062.

De Santo, E.M., and J ones, P.J.S. 2007. The Darwin Mounds: from undiscovered coral to the development of an offshore marine protected area regime. Bulletin of Marine Science 81: 147-156.

Elith, J., Graham, C.H., Anderson, R.P., Dudik, M., Ferrier, S., Guisan, A., Hijmans, R.J ., Huettmann, F., Leathwick, J.R., Lehmann, A., Li, J., Lohmann, L.G., Loiselle, B. A., Manion, G., Moritz, C., Nakamura, M., Nakazawa, Y., McC. Overton, J., Peterson, A.T., Phillips, S.J., occurrence data. Ecography 29: 129-151. 
703

704

705

706

707

708

709

710

711

712

713

714

715

716

717

718

719

720

721

722

723

724

725

726

727

Elith, J., Phillips, S.J., Hastie, T., Dudik, M., En Chee, Y., and Yates, C.J. 2011. A statistical explanation of MaxEnt for ecologists. Diversity and Distributions 17: 43-57.

Feely, K.J ., and Silman, M.R. 2011. Keep collecting: accurate species distribution modelling requires more collections than previously thought. Diversity and Distributions 17: 1132-1140.

Fielding, A.H., and Bell, J.F. 1997. A review of methods for the assessment of prediction errors in conservation presence/ absence models. Environmental Conservation 24: 38-49.

Garcia, H.E., Locarnini, R.A., Boyer, T.P., and Antonov, J.I. 2006a. World Ocean Atlas 2005, Volume 3: Dissolved Oxygen, Apparent Oxygen Utilization, and Oxygen Saturation. Levitus, S. (Ed.). NOAA Atlas NESDIS 63, U.S. Government Printing Office, Washington, D.C., 342 pp.

Garcia, H.E., Locarnini, R.A., Boyer, T.P., and Antonov, J.I. 2006b. World Ocean Atlas 2005, Volume 4: Nutrients (phosphate, nitrate, silicate). Levitus, S. (Ed.). NOAA Atlas NESDIS 64, U.S. Government Printing Office, Washington, D.C., 396 pp.

Glover, A.G., and Smith, C.R. 2003. The deep-sea floor ecosystem: current status and prospects of anthropogenic change by the year 2025. Environmental Conservation 30: 219-241.

Gooday, A.J., Aranda da Silva, A., and Pawlowski, J. 2011. Xenophyophores (Rhizaria, Foraminifera) from the Nazare Canyon (Portuguese margin, NE Atlantic). Deep-Sea Research II 58: 2401-2419.

Gooday, A.J., Bett, B.J., and Pratt, D.N. 1993. Direct observation of episodic growth in an abyssal xenophyophore (Protista). Deep-Sea Research I 40: 2131-2143.

Gooday, A.J ., and Tendal, O.S. 2002. Class Xenophyophorea. In: Lee, J .J ., Huttner, J ., and Bovee, E.C. (Eds). 2002. An illustrated guide to the Protozoa, $2^{\text {nd }}$ ed. Society of Protozoologists and Allen Press, Lawrence, Kansas. Pp. 1086-1097.

Guinotte, J.M., and Davies, A.J . 2012. Predicted deep-sea coral habitat suitability for the U.S. West Coast. Report to NOAA-NMFS. 85 pp.

Guisan, A., Graham, C.H., Elith, J., and Huettmann, F. 2007. Sensitivity of predictive species distribution models to change in grain size. Diversity and Distributions 13: 332-340. 
Haeckel, E. 1889. Report on the deep-sea keratosa. Report on the scientific results of the voyage of H. M. S. Challenger during the years 1873-76. Zoology 32: 1-92. Hori, S., Tsuchiya, M., Nishi, S., Arai, W., Yoshida, T., and Takami, H. 2013. Active bacterial flora surrounding Foraminifera (Xenophyophorea) living on the deep-sea floor. Bioscience, Biotechnology and Biochemistry 77: 381-384.

Hughes, J.A., and Gooday, A.J . 2004. Associations between living benthic foraminifera and dead tests of Syringammina fragilissima (Xenophyophorea) in the Darwin Mounds region (NE Atlantic). Deep-Sea Research I 51: 1741-1758.

J enness, J. 2012. DEM Surface Tools. J enness Enterprises.

J ones, K.H. 1998. A comparison of algorithms used to compute hill slope as a property of the DEM. Computers and Geosciences 24:315-323.

Kamenskaya, O.E., Melnik, V.F., and Gooday, A.J . 2013. Giant protists (xenophyophores and komokiaceans) from the Clarion-Clipperton ferromanganese nodule field (Eastern Pacific). Biology Bulletin Reviews 3: 388-398.

Koslow, J.A., Boehlert, G.W., Gordon, J.D.M., Haedrich, R. L., Lorance, P., and Parin, N. 2000. Continental slope and deep-sea fisheries: implications for a fragile ecosystem. J ournal of Marine Science 57: 548-557. Laureillard, J., Mejanelle, L., and Sibuet, M. 2004. Use of lipids to study the trophic ecology of deep-sea xenophyophores. Marine Ecology Progress Series 270: 129-140.

Lecroq, B., Gooday, A.J., Tsuchiya, M., and Pawlowski, J. 2009. A new genus of xenophyophores (Foraminifera) from J apan Trench: morphological description, molecular phylogeny and elemental analysis. Zoological J ournal of the Linnaean Society 156: 455-464. from photographs. Vidensk Meddr Dansk Naturh Foren 139: 263-336. for the community structure of deep-sea benthos. American Zoologist 31: 886-900. 
Levin, L.A., and Gooday, A.J . 1992. Possible roles for xenophyophores in deep-sea carbon cycling. In: Rowe, G.T., and Pariente, V. (Eds.). 1992. Deep-sea food chains and the global carbon cycle. 757 Springer Netherlands. pp. 93-104.

Levin, L.A., and Thomas, C.L. 1988. The ecology of xenophyophores (Protista) on eastern Pacific seamounts. Deep Sea Research 35: 2003-2027.

Levin, L.A., DeMaster, D.J ., McCann, L.D., and Thomas, C.L. 1986. Effects of giant protozoans (class: Xenophyophorea) on deep-seamount benthos. Marine Ecology - Progress Series 29: 99-104.

Mohn, C., Rengstirf, A., White, M., Duineveld, G., Mienis, F., Soetaert, K., and Grehan, A. 2014. Linking benthic hydrodynamics and cold-water coral occurrences: high-resolution model study at three cold-water coral provinces in the NE Atlantic. Progress in Oceanography 122: 92-104

Oey, L.-Y. 1997. Eddy energetic in the Faroe-Shetland channel: a model resolution study. Continental Shelf Research 17: 1929-1944.

Ortega-Huerta, M.A., and Peterson, A.T. 2008. Modelling ecological niches and predicting geographic distributions: a test of six presence-only methods. Revista Mexicana de Biodiversidad 79: 205-216.

Orton, J.H. 1920. Sea-temperature, breeding and distribution in marine animals. J ournal of the Marine Biological Association of the United Kingdom 12: 339-366. suggests that the xenophyophorean Syringammina corbicula is a Foraminiferan. J ournal of Eukaryote Microbiology 50: 483-487. Pfannkuche, O. 1993. Benthic response to the sedimentation of particulate organic matter at the BIOTRANS station, $47^{\circ} \mathrm{N}, 20^{\circ} \mathrm{W}$. Deep-Sea Research II 40: 135-149. geographic distributions. Ecological Modelling 190: 231-259. 
779

780

781

782

783

784

785

786

787

788

789

790

791

792

793

794

795

796

797

798

799

800

801

802

Phillips, S.J., and Dudik, M. 2008. Modelling of species distributions with Maxent: new extensions and a comprehensive evaluation. Ecography 31: 161-175.

Rengstorf, A. M., Grehan, A., Yesson, C., and Brown, C. 2012. Towards high-resolution habitat suitability modelling of vulnerable marine ecosystems in the deep-sea: resolving terrain attribute dependencies. Marine Geodesy 35: 343-361.

Rengstorf, A. M., Yesson, C., Brown, C., and Grehan, A.J . 2013. High-resolution habitat suitability modelling can improve conservation of vulnerable marine ecosystems in the deep sea. J ournal of Biogeography 40: 1702-1714.

Richardson, S. L. 2001. Syringammina corbicula sp. nov. (Xenophyophorea) from the Cape Verde Plateau, E. Atlantic. J ournal of Foraminiferal Research 31: 201-209.

Riemann, F., Tendal, O.S., and Gingele, F.X. 1993. Reticulammina Antarctica nov. spec.

(Xenophyophora, Protista) from the Weddell Sea, and aspects of the nutrition of xenophyophores. Polar Biology 13: 543-547.

Roden, G.I. 1987. Effects of seamounts and seamount chains on ocean circulation and thermohaline structure. In: Keating, B. Fryer, P., Batizar, R., and Boehlert, G. (Eds.). 1987. Seamounts, islands, and atolls. Geophysical Monograph No. 43, American Geophysical Union. pp. 335-354.

Ross, R.E., and Howell, K.L. 2012. Use of predictive habitat modelling to assess the distribution and extent of the current protection of 'listed' deep-sea habitats. Diversity and Distributions 19: 433445.

Schulze, F.E. 1904. Über den Bau und die Entwicklung gewisser Tiefseeorganismen. Sitzungsberichte der Königlich-preussischen Akademie der Wissenschaften zu Berlin 53: 1387.

Schulze, F.E. 1907. Die Xenophyophoren: Eine besondere Gruppe der Rhizopoden. Wissenschaftliche Ergebnisse der Deutschen Tiefsee-Expedition auf dem Dampfer "Valdivia" 1898-1899. G. Fischer. 
803

804

805

806

807

808

809

810

811

812

813

814

815

816

817

818

819

820

821

822

823

824

825

826

827

828

Shumchenia, E.J ., and King, J.W. 2010. Comparison of methods for integrating biological and physical data for marine habitat mapping and classification. Continental Shelf Research 30: 17171729.

Smith, C.R., and Demopoulos, A.W.J. 2003. The deep Pacific ocean floor. In: Tyler, P.A. (Ed.) 2003. Ecosystems of the deep oceans. Ecosystems of the world 28: 179-218. Elsevier: Amsterdam. ISBN.

Tendal, O.S. 1972. A monograph of the Xenophyophoria (Rhizopodea, Protozoa). Doctoral dissertation, Danish Science Press.

Tendal, O.S. 1979. Aspects of the biology of Komokiacea and Xenophyophoria. Sarsia 64: 13-17.

Tendal, O.S. 1996. Synoptic checklist and bibliography of the Xenophyophorea (Protista), with a zoogeographical survey of the group. Galathea Report 17 (1995-1996): 79-101.

Tendal, O.S., and Gooday, A.J. 1981. Xenophyophoria (Rhizopoda, Protozoa) in bottom photographs from the bathyal and abyssal NE Atlantic. Oceanologica Acta 4: 415-422.

Tendal, O.S., and Lewis, K.B. 1978. New Zealand xenophyophores: Upper bathyal distribution, photographs of growth position, and a new species. New Zealand J ournal of Marine and Freshwater Research 12: 197-203.

Thrush, S.F., and Dayton, P.K. 2002. Disturbance to marine benthic habitats by trawling and dredging: implications for marine biodiversity. Annual Review of Ecology and Systematics 33: 449473.

Tittensor, D.P., Baco, A.R., Hall-Spencer, J.M., Orr, J.C., and Rogers, A.D. 2010. Seamounts as refugia from ocean acidification for cold-water stony corals. Marine Ecology 31 (Suppl. 1): 212-225.

Warren, D.L., and Seifert, S.N. 2011. Ecological niche modelling in Maxent: the importance of model complexity and the performance of model selection criteria. Ecological Applications 21: 335342.

Wilson, M. F.J ., O'Connell, B., Brown, C., Guinan, J.C., and Grehan, A.J . 2007. Multiscale terrain analysis of multibeam bathymetry data for habitat mapping on the Continental Slope. Marine Geodesy 30:3-35. 
829 Wisz, M.S., Hijmans, R.J ., Li, J ., Peterson, A.T., Graham, C.H., Guisan, A., and NCEAS Predicting 830 Species Distributions Working Group. 2008. Effects of sample size on the performance of species 831 distribution models. Diversity and Distributions 14: 763-773.

832 Yesson, C., Taylor, M.L., Tittensor, D.P., Davies, A.J., Guinotte, J., Baco, A., Black, J., Hall-

833 Spencer, J.M., and Rogers, A.D. 2012. Global habitat suitability of cold-water octocorals. J ournal of 834 Biogeography 39: 1278-1292. 


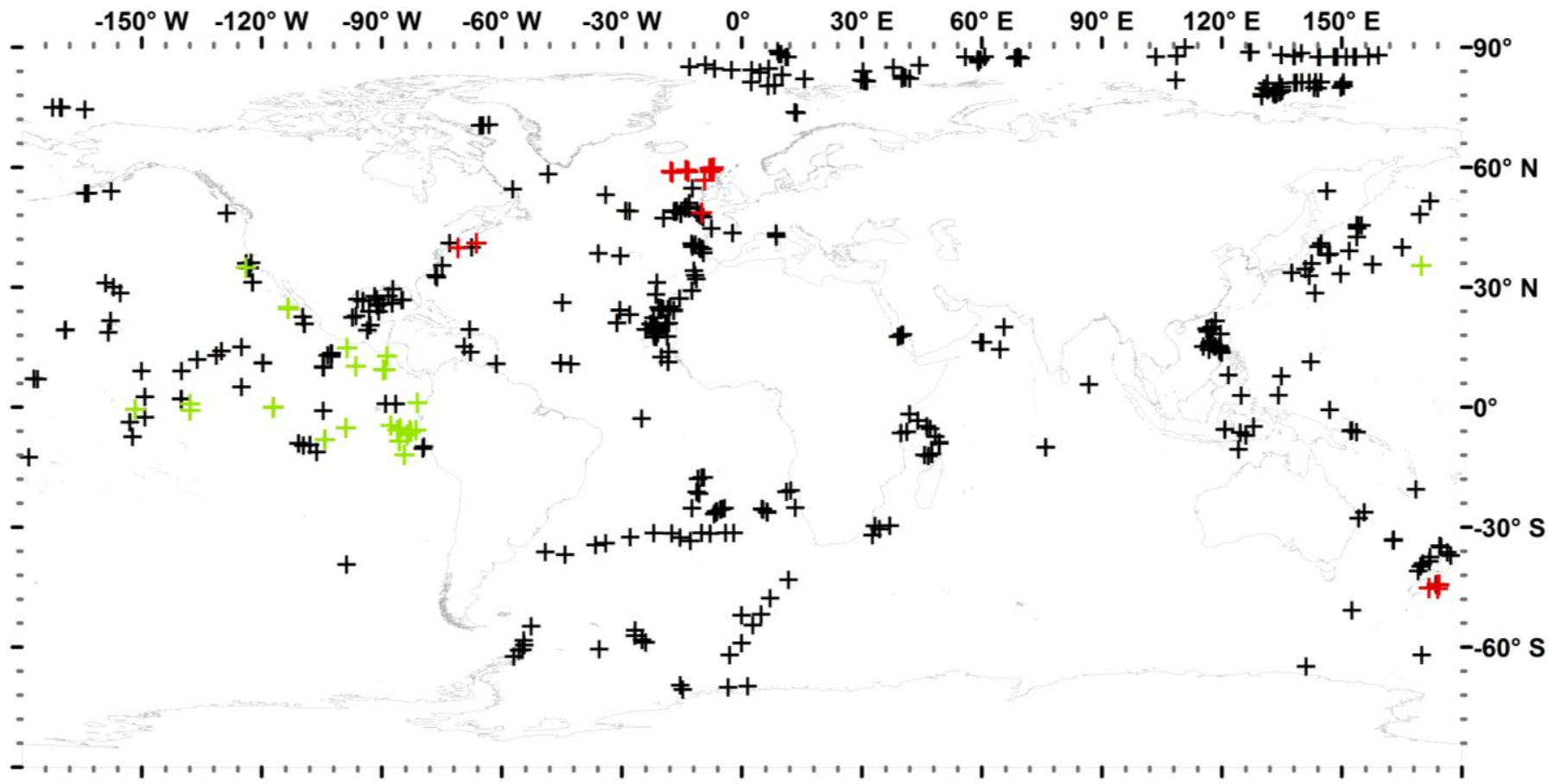

Figure 1: Global sampling locations for xenophyophores. Taxa are colour-coded: Syringammina fragilissima - red; Stannophyllum zonarium - green; remaining Xenophyophorea - black. 

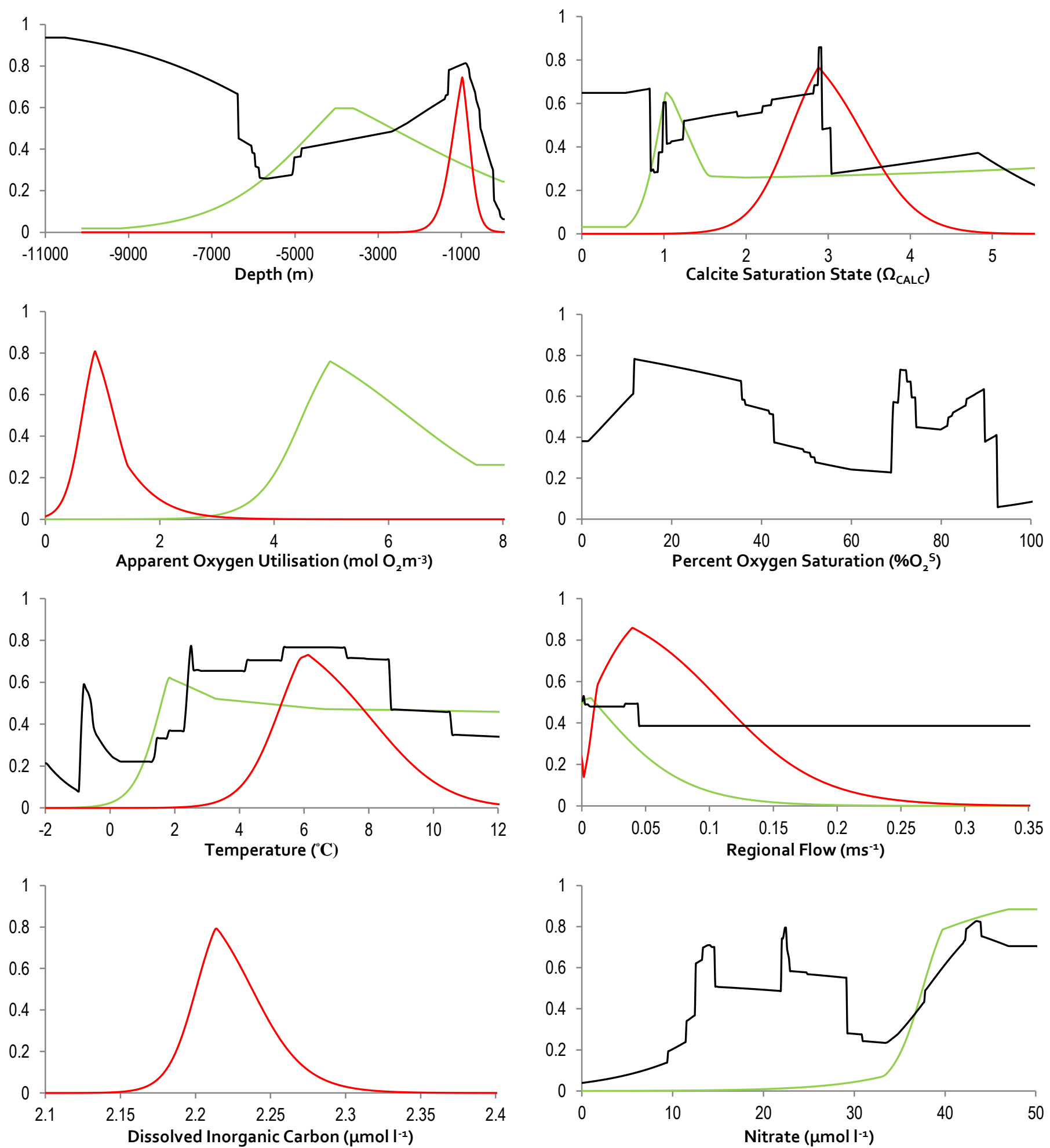

Figure 2: Variable response curves for global Maxent habitat suitability models of xenophyophore taxa. Note $Y$ axis is habitat suitability - $0(\mathrm{~min})$ to $1(\max )$ in all cases. Taxa are colour-coded as in Figure 1: Xenophyophorea - black; Syringammina fragilissima - red; Stannophyllum zonarium - green. 


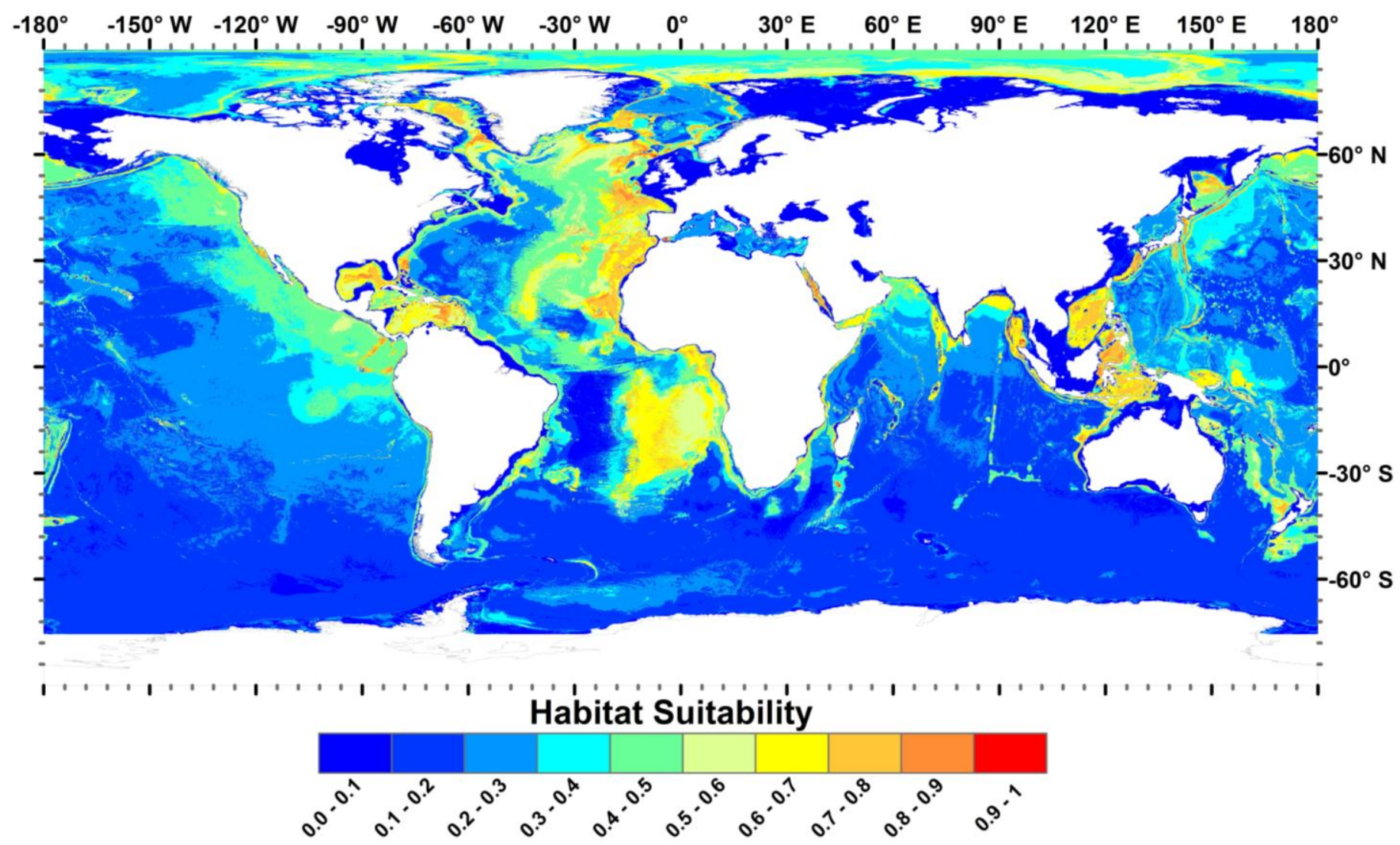

Figure 3: Global habitat suitability for Xenophyophorea at 30 arc-second resolution. Based on Maxent output (logistic). Habitat suitability values of 0 illustrate minimally suitable environmental conditions in an area. Habitat suitability values of 1 illustrate maximally suitable environmental conditions in an area. 


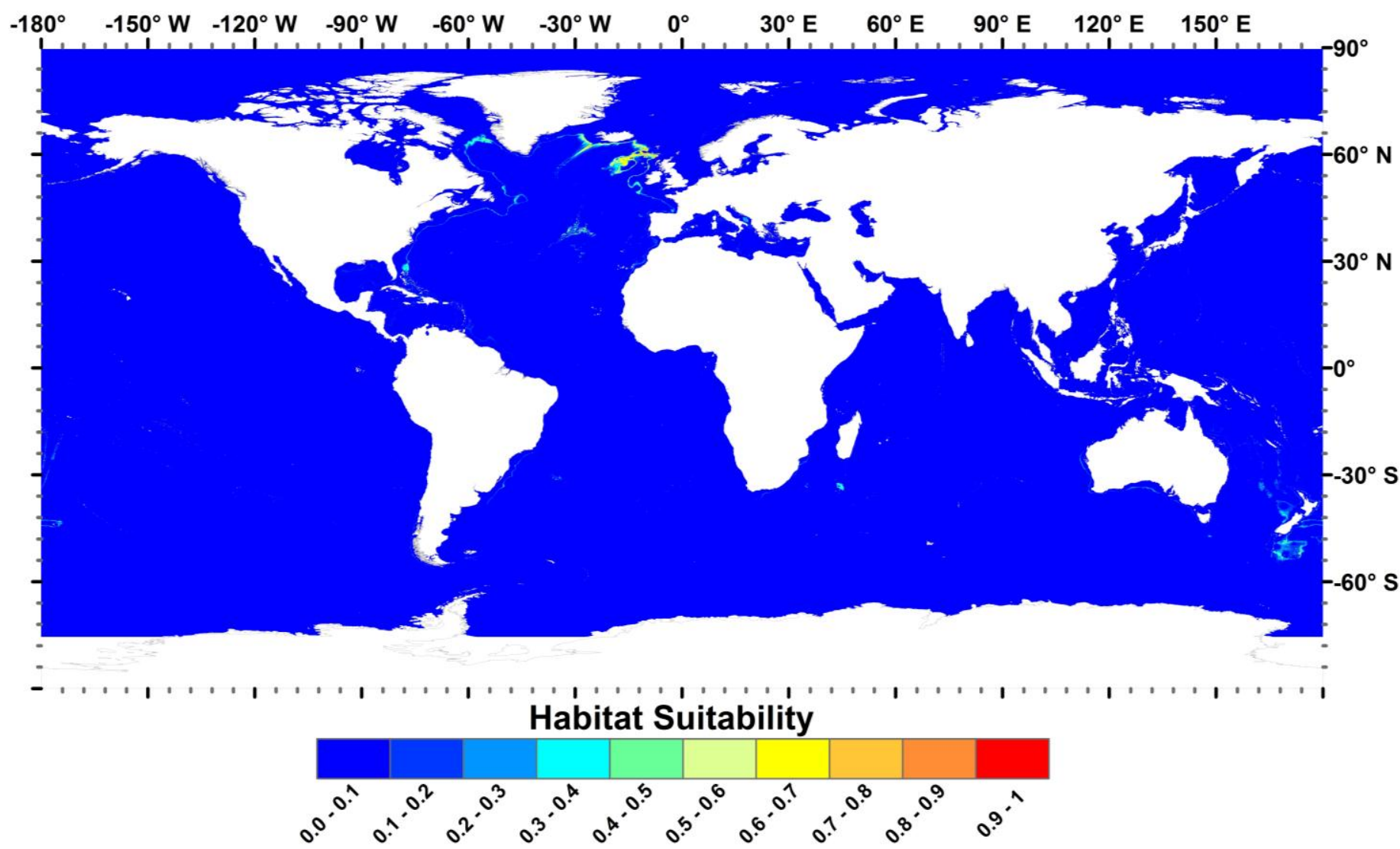

Figure 4: Global habitat suitability for the xenophyophore species Syringammina fragilissima at 30 arc-second resolution. Based on Maxent output (logistic). Habitat suitability values of 0 illustrate minimally suitable environmental conditions in an area. Habitat suitability values of 1 illustrate maximally suitable environmental conditions in an area. 


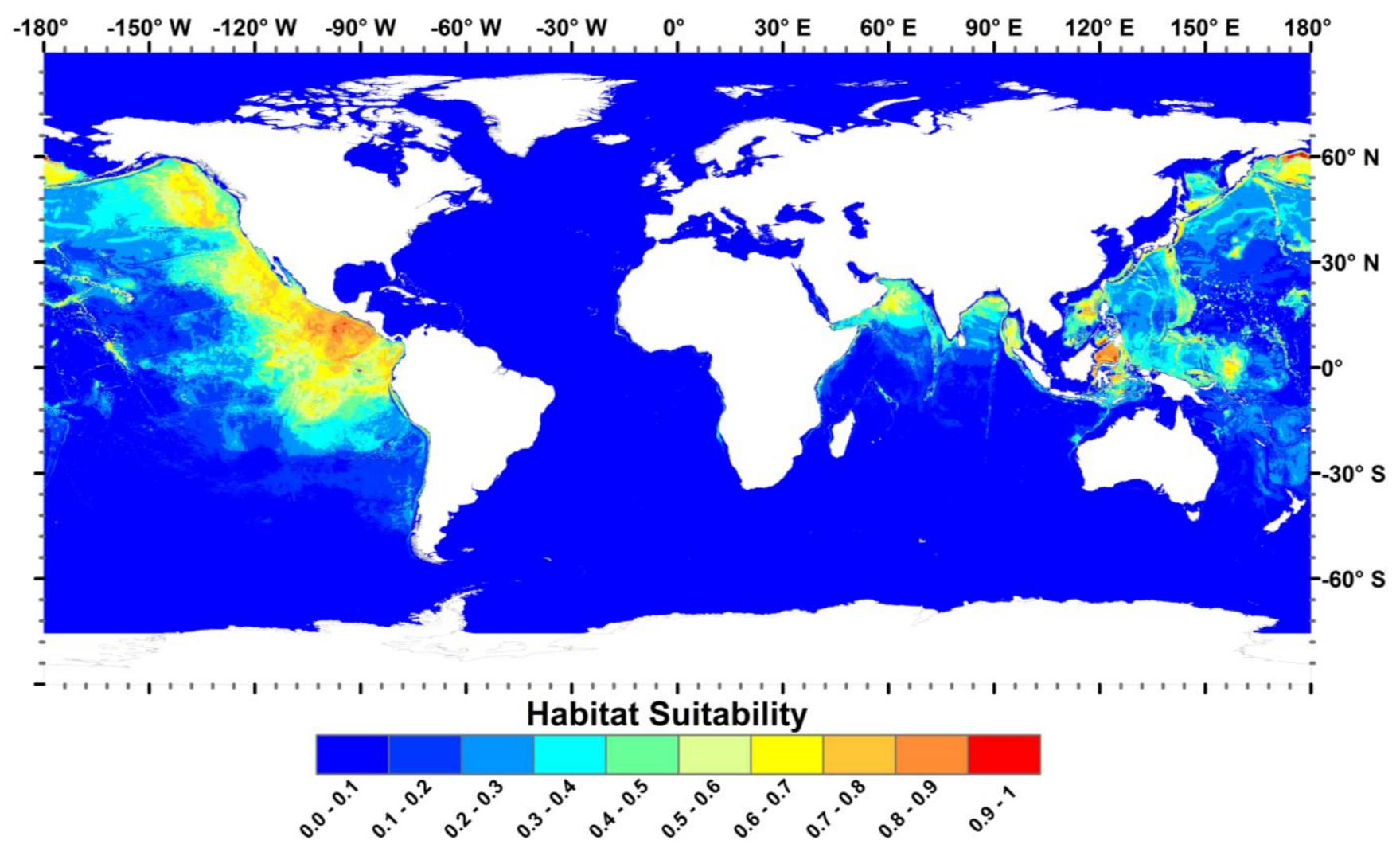

Figure 5: Global habitat suitability for the xenophyophore species Stannophyllum zonarium at 30 arc-second resolution. Based on Maxent output (logistic). Habitat suitability values of 0 illustrate minimally suitable environmental conditions in an area. Habitat suitability values of 1 illustrate maximally suitable environmental conditions in an area. 
Table 1: Number of geo-referenced records available per xenophyophore taxon. Only one record per 30 arc-second cell was retained for Maxent analyses. Number of species for which geo-referenced records were available $=68$.

\begin{tabular}{|c|c|c|c|}
\hline Genus & Species & No. records & No. records retained in analysis \\
\hline \multirow[t]{7}{*}{ Aschemonella } & carpathica & 5 & \\
\hline & catenata & 4 & \\
\hline & composita & 12 & \\
\hline & grandis & 9 & \\
\hline & ramuliformis & 85 & \\
\hline & scabra & 80 & \\
\hline & Unknown & 58 & \\
\hline \multirow[t]{4}{*}{ Cerelasma } & gyrosphaera & 2 & \\
\hline & lamellosa & 1 & \\
\hline & massa & 7 & \\
\hline & Unknown & 1 & \\
\hline Cerelpemma & radiolarium & 4 & \\
\hline \multirow[t]{7}{*}{ Galatheammina } & calcarea & 9 & \\
\hline & discoveryi & 4 & \\
\hline & erecta & 13 & \\
\hline & lamina & 1 & \\
\hline & microconcha & 3 & \\
\hline & tetraedra & 4 & \\
\hline & Unknown & 7 & \\
\hline \multirow[t]{2}{*}{ Holopsamma } & argillaceum & 1 & \\
\hline & cretaceum & 1 & \\
\hline \multirow[t]{3}{*}{ Homogammina } & lamina & 13 & \\
\hline & maculosa & 20 & \\
\hline & Unknown & 3 & \\
\hline Ma udammina & arenaria & 1 & \\
\hline Nazareammina & tenera & 2 & \\
\hline \multirow[t]{2}{*}{ Occultammina } & profunda & 1 & \\
\hline & Unknown & 1 & \\
\hline \multirow[t]{4}{*}{ Psammetta } & arenocentrum & 1 & \\
\hline & erythrocytomorpha & 3 & \\
\hline & globosa & 6 & \\
\hline & Unknown & 4 & \\
\hline \multirow[t]{8}{*}{ Psammina } & delicate & 6 & \\
\hline & fusca & 1 & \\
\hline & globigerina & 3 & \\
\hline & nummulina & 4 & \\
\hline & plakina & 1 & \\
\hline & sabulosa & 3 & \\
\hline & zonaria & 1 & \\
\hline & Unknown & 12 & \\
\hline Psammopemma & calcareum & 1 & \\
\hline \multirow[t]{9}{*}{ Reticulammina } & antarctica & 1 & \\
\hline & cerebreformis & 10 & \\
\hline & cretacea & 1 & \\
\hline & labyrinthica & 34 & \\
\hline & lamellata & 3 & \\
\hline & maini & 1 & \\
\hline & novazealandica & 3 & \\
\hline & plicata & 1 & \\
\hline & Unknown & 26 & \\
\hline Semipsammina & Unknown & 2 & \\
\hline Shinkaiya & lindsayi & 1 & \\
\hline Spiculammina & delicata & 1 & \\
\hline Stannarium & concretum & 1 & \\
\hline \multirow[t]{4}{*}{ Stannoma } & alatum & 1 & \\
\hline & coralloides & 5 & \\
\hline & dendroides & 11 & \\
\hline & Unknown & 1 & \\
\hline \multirow[t]{11}{*}{ Stannophyllum } & alatum & 4 & \\
\hline & annectens & 1 & \\
\hline & concretum & 1 & \\
\hline & flustraceum & 2 & \\
\hline & fragilis & 1 & \\
\hline & globigerinum & 19 & \\
\hline & granularium & 11 & \\
\hline & indistinctum & 3 & \\
\hline & mollum & 9 & \\
\hline & pertusum & 1 & \\
\hline & radiolarium & 3 & \\
\hline
\end{tabular}




\begin{tabular}{llcc}
\hline & reticulatum & 2 & \\
& setosum & 1 & \\
& venosum & 1 & \\
& zonarium & 31 & \\
Syringa mmina & Unknown & 3 & 40 \\
& corbicula & 4 & \\
& fragilissima & 49 & \\
& minuta & 1 & \\
& reticulata & 2 & \\
Unknown & tasmanensis & 7 & \\
Total & Unknown & 10 & \\
\hline
\end{tabular}

Table 2: Summary of geophysical and environmental variables used in this study. All variables are stored in an ArcGIS file geodatabase. Superscript notes indicate particular analysis or treatment of data.

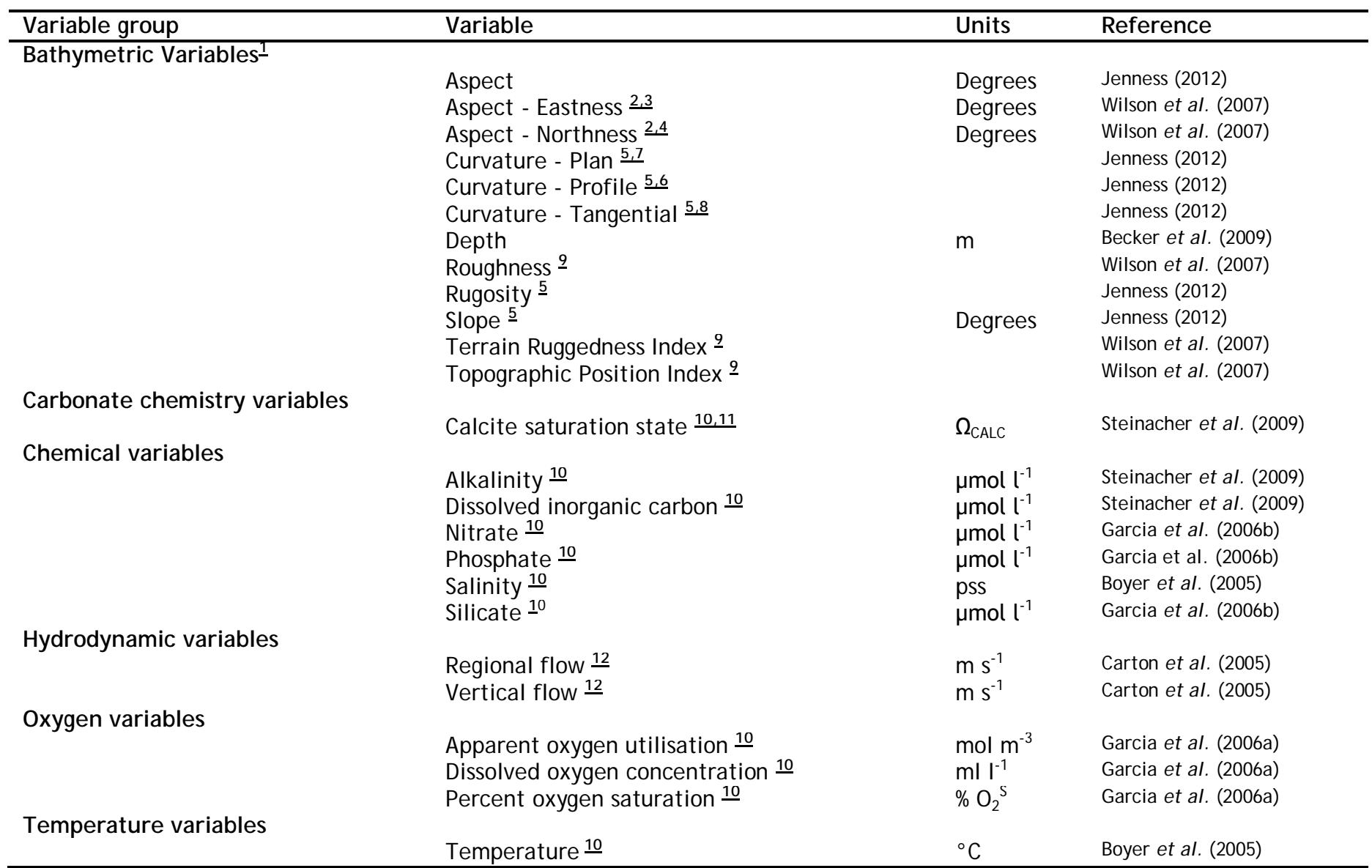


$\underline{1}$ Derived from SRTM30 bathymetry.

$\underline{\mathbf{2}}$ Calculated in ArcGIS 10 .

$\underline{3}$ Modified calculation from Wilson et al. (2007) using $\operatorname{Sin}(($ Aspect $* \pi) / 180$, to produce $1=$ east and $-1=$ west orientation.

$\underline{4}$ Modified calculation from Wilson et al. (2007) using $\operatorname{Cos}\left(\left(\right.\right.$ Aspect $\left.{ }^{*} \pi\right) / 180$, to produce $1=$ north and $-1=$ south orientation.

$\underline{\mathbf{5}}$ Calculated using the 4 cell method in J enness (2012).

$\underline{6}$ Longitudinal curvature in J enness (2012) and defined as "Longitudinal curvatures are set to positive when the curvature is concave (i.e. when water would decelerate as it flows over this point). Negative values indicate convex curvature where stream flow would accelerate." Zero indicates an undefined value.

7 Defined in J enness (2012) as "Plan curvatures are set to positive when the curvature is convex (i.e. when water would diverge as it flows over this point). Negative values indicate concave curvature where stream flow would converge." Zero indicates an undefined value.

$\underline{8}$ Defined in Jenness (2012) as "Tangential curvatures are set to positive when the curvature is convex (i.e. when water would diverge as it flows over this point). Negative values indicate concave curvature where stream flow would converge." Zero indicates an undefined value.

$\underline{9}$ Calculated using GDAL DEM Tool. Values at zero indicate flat areas, higher values indicate rough and variable terrain.

$\underline{10}$ Variable creation process followed the Davies and Guinotte (2011) upscaling approach.

$\underline{11}$ Created using SRES1B scenario data from the years 2000-2010.

$\underline{12}$ SODA data extracted from version 2.0.4, monthly means for the years 1990-2007.

Table 3: Test AUC values for global Maxent habitat suitability models of xenophyophore taxa based on single variables. The highest AUC scores in each variable group are highlighted in bold and underlined for each taxon.

\begin{tabular}{|c|c|c|c|c|}
\hline Variable group & Variable & Xenophyophorea & $\begin{array}{l}\text { Syringammina } \\
\text { fragilissima }\end{array}$ & $\begin{array}{l}\text { Stannophyllum } \\
\text { zonarium }\end{array}$ \\
\hline \multirow[t]{12}{*}{ Bathymetric Variables } & Aspect & 0.535 & 0.672 & 0.615 \\
\hline & Eastness of aspect & 0.514 & 0.509 & 0.507 \\
\hline & Northness of aspect & 0.518 & 0.614 & 0.529 \\
\hline & Plan curvature & 0.562 & 0.500 & 0.500 \\
\hline & Profile curvature & 0.577 & 0.500 & 0.500 \\
\hline & Tangential curvature & 0.560 & 0.500 & 0.500 \\
\hline & Depth & $\underline{0.686}$ & $\underline{0.987}$ & $\underline{0.696}$ \\
\hline & Roughness & $\overline{0.571}$ & $\overline{0.548}$ & $\overline{0.666}$ \\
\hline & Rugosity & 0.544 & 0.583 & 0.688 \\
\hline & Terrain ruggedness index & 0.561 & 0.574 & 0.659 \\
\hline & Topographic position index & 0.598 & 0.393 & 0.408 \\
\hline & Slope & 0.554 & 0.577 & 0.673 \\
\hline \multirow{7}{*}{$\begin{array}{l}\text { Carbonate chemistry variables } \\
\text { Chemical variables }\end{array}$} & Calcite saturation state & 0.654 & 0.957 & 0.784 \\
\hline & Alkalinity & 0.669 & 0.961 & 0.808 \\
\hline & Dissolved inorganic carbon & 0.689 & 0.977 & 0.840 \\
\hline & Nitrate & 0.728 & 0.903 & 0.913 \\
\hline & Phosphate & 0.703 & 0.935 & 0.891 \\
\hline & Salinity & 0.714 & 0.834 & 0.318 \\
\hline & Silicate & 0.717 & 0.931 & 0.908 \\
\hline \multirow[t]{2}{*}{ Hydrodynamic variables } & Regional flow & $\underline{0.500}$ & 0.810 & $\underline{0.633}$ \\
\hline & Vertical flow & 0.491 & 0.500 & 0.500 \\
\hline \multirow[t]{3}{*}{ Oxygen variables } & Apparent oxygen utilisation & 0.733 & 0.910 & 0.907 \\
\hline & Dissolved oxygen concentration & 0.725 & 0.873 & 0.895 \\
\hline & Percent oxygen saturation & 0.747 & 0.891 & 0.897 \\
\hline Temperature variables & Temperature & 0.720 & 0.986 & 0.776 \\
\hline
\end{tabular}


Table 4: Model evaluation statistics for global Maxent habitat suitability models of xenophyophore taxa based on multiple variables. The three most important variables for each taxon (jack-knife of regularised training gain) are highlighted in bold and underlined. * indicates the variable that reduced the training gain most when omitted and therefore contained the most information that was not present in other variables. $t$ indicates the variable with the highest training gain when used in isolation and which thus had the most useful information by itself. Thresholds are based on the maximum sensitivity plus specificity of the test dataset.

\begin{tabular}{|c|c|c|c|}
\hline Statistic & Xenophyophorea & $\begin{array}{l}\text { Syringa mmina } \\
\text { fragilissima }\end{array}$ & $\begin{array}{l}\text { Stannophyllum } \\
\text { zonarium }\end{array}$ \\
\hline \multicolumn{4}{|l|}{ Model evaluation } \\
\hline Test AUC & 0.836 & 0.997 & 0.941 \\
\hline Test gain & 0.841 & 4.580 & 1.768 \\
\hline Entropy & 8.632 & 4.512 & 7.551 \\
\hline \multicolumn{4}{|l|}{ Threshold } \\
\hline Logistic value & 0.379 & 0.100 & 0.276 \\
\hline $\begin{array}{l}\text { Test omission } \\
\text { (\%) }\end{array}$ & 0.200 & 0.000 & 0.000 \\
\hline Fractional & 0.244 & 0.010 & 0.124 \\
\hline Probability & $4.83 \times 10^{-64}$ & $7.59 \times 10^{-25}$ & $6.70 \times 10^{-9}$ \\
\hline \multicolumn{4}{|l|}{$\begin{array}{l}\text { Regularised } \\
\text { training gain in } \\
\text { isolation }\end{array}$} \\
\hline Depth & 0.228 & 3.153 & 0.109 \\
\hline $\begin{array}{l}\text { Calcite } \\
\text { saturation } \\
\text { state }\end{array}$ & 0.114 & $\underline{2.115}$ & 0.172 \\
\hline \multicolumn{4}{|l|}{$\begin{array}{l}\text { inorganic } \\
\text { carbon }\end{array}$} \\
\hline Nitrate & $\underline{0.331}$ & - & 1.254 \\
\hline Regional flow & $\overline{0.004}$ & 0.608 & $\overline{0.016}$ \\
\hline \multicolumn{4}{|l|}{$\begin{array}{l}\text { oxygen } \\
\text { utilisation }\end{array}$} \\
\hline Percent & 0.286 & - & \\
\hline $\begin{array}{l}\text { oxygen } \\
\text { saturation }\end{array}$ & & & \\
\hline Temperature & $0.339 t^{*}$ & $3.241 \dagger^{*}$ & 0.441 \\
\hline
\end{tabular}


